\title{
COLLECTIE NEDERLANDSE NATUURFILMS
}

In het voorjaar van I9Io toerden de gebroeders Albert en Willy Mullens onder de naam Alberts Frères voor de zoveelste keer met een uitgebreid filmprogramma door het land. Als een van hun 'hooge attractiën' kondigden 'les Rois des bioscopes', zoals zij zichzelf bescheiden betitelden, ons ALLER VRIENDJES: DE VOGELS EN HUNNE OMGEVING aan. De film kon op de nodige waardering rekenen. Er was ook verbazing over de technische prestatie die de makers hadden geleverd om de vogels zo goed in beeld te krijgen. Zo vond een journalist het 'onbegrijpelijk (...) hoe het mogelijk is de vogels zoo uit te beelden in hun nesten, te midden hunner jongen'. ${ }^{.}$Aan het belang van de film werd niet getwijfeld. Typerend was de ontboezeming van een andere journalist: 'En daarin zit hem nu mijn groote sympathie voor deze fraaie vertooning, want vogels kennen, is de vogels liefhebben.'2 Hoewel ons ALLER VRIEndJes zeer waarschijnlijk geen eigen productie van de gebroeders Mullens was (vermoedelijk hadden ze hem in het buitenland aangekocht), wordt met deze film een toon gezet die tot op de dag van vandaag bij natuurfilms opgeld doet. Een goede natuurfilm moet iets laten zien wat de toeschouwer normaliter niet ziet, bijvoorbeeld omdat hij een stadsbewoner is, maar vooral ook omdat het menselijk oog tekortschiet. Bovendien moet de film bij diezelfde toeschouwer begrip creëren voor de natuur, in het bijzonder voor de dieren die daarin leven.

In de bijna honderd jaar die zijn verstreken sinds ons ALLER VRIENDJES door de gebroeders Mullens in roulatie werd gebracht, zijn in Nederland talloze natuurfilms gemaakt en vertoond - in bioscopen, verenigingszalen, klaslokalen en de laatste decennia vooral op de televisie. Sommige hebben een groot publiek bereikt (zo kochten bijna negenhonderdduizend mensen een bioscoopkaartje om Haanstra's BIJ DE BEESTEN AF (I973) te zien), terwijl andere alleen in beperkte kring zijn vertoond. Voor zover ze al de tand des tijds hebben doorstaan en hun weg naar een audiovisueel archief hebben gevonden, is het lastig om meer over de Nederlandse natuurfilms te weten te komen. Welke films over welke onderwerpen zijn er gemaakt, wie waren de makers, zijn deze films bewaard en zo ja, waar kunnen ze bekeken worden? Om vragen als deze te kunnen beantwoorden zijn het Nederlands Instituut voor Beeld en Geluid en het Nationaal Natuurhistorisch Museum Naturalis met het project 'Collectie Nederlandse Natuurfilms' gestart. Dit artikel begint met een terugblik op de geschiedenis van de Nederlandse natuurfilm aan de hand van de makers ervan. 
Vervolgens komen de ontwikkelingen in stijl en techniek aan de orde. Daarna volgt een bespreking van de voortgang van het project 'Collectie Nederlandse Natuurfilms'. Onder meer worden de resultaten van een verkennend onderzoek onder natuurorganisaties en omroepen bekend gemaakt.

\section{Pioniers}

Ad. Burdet (I860-I940) geldt als de pionier van de Nederlandse natuurfilm. Burdet, een Zwitser die zich na zijn huwelijk met een vrouw uit een rijke Nederlandse familie in Bloemendaal had gevestigd, was op aanraden van de voorman van de Nederlandse natuurbescherming Jac. P. Thijsse vogels gaan fotograferen. Gezeten in een schuiltent - die hij door zijn persoonlijke chauffeur met de auto ter plekke liet brengen - wachtte hij, vaak vergezeld van zijn vrouw, geduldig af tot hij een goede opname kon maken. Hij was een tegenstander van het verstoren van nesten om goede foto's te krijgen. Veel succes had hij met zijn stereoscopische foto's die de Nederlandse Vereniging tot Bescherming van Vogels in series op de markt bracht. Ook werden zijn foto's als illustratie in boeken en tijdschriften zoals De Levende Natuur afgedrukt. Tijdens de Eerste Wereldoorlog begon Burdet ook met filmen. ${ }^{3}$

In I920 was Burdets eerste voG ELFILM gereed, waarin 'het bedrijvige leven van onze wei-, strand- en boschvogels' te zien was. ${ }^{4}$ In de volgende jaren kwam Burdet steeds met nieuwe opnamen, die hetzij in reeds bestaande films werden verwerkt hetzij als een nieuwe film werden gepresenteerd. Deze waren de grote attractie op jaarvergaderingen van de Vereniging tot Behoud van Natuurmonumenten of de Vereniging tot Bescherming van Vogels. Van beide verenigingen was Burdet bestuurslid. Thijsse, die bij de vertoning meestal als explicateur optrad, vergeleek de opnamen van Burdet met beroemde wijnen:
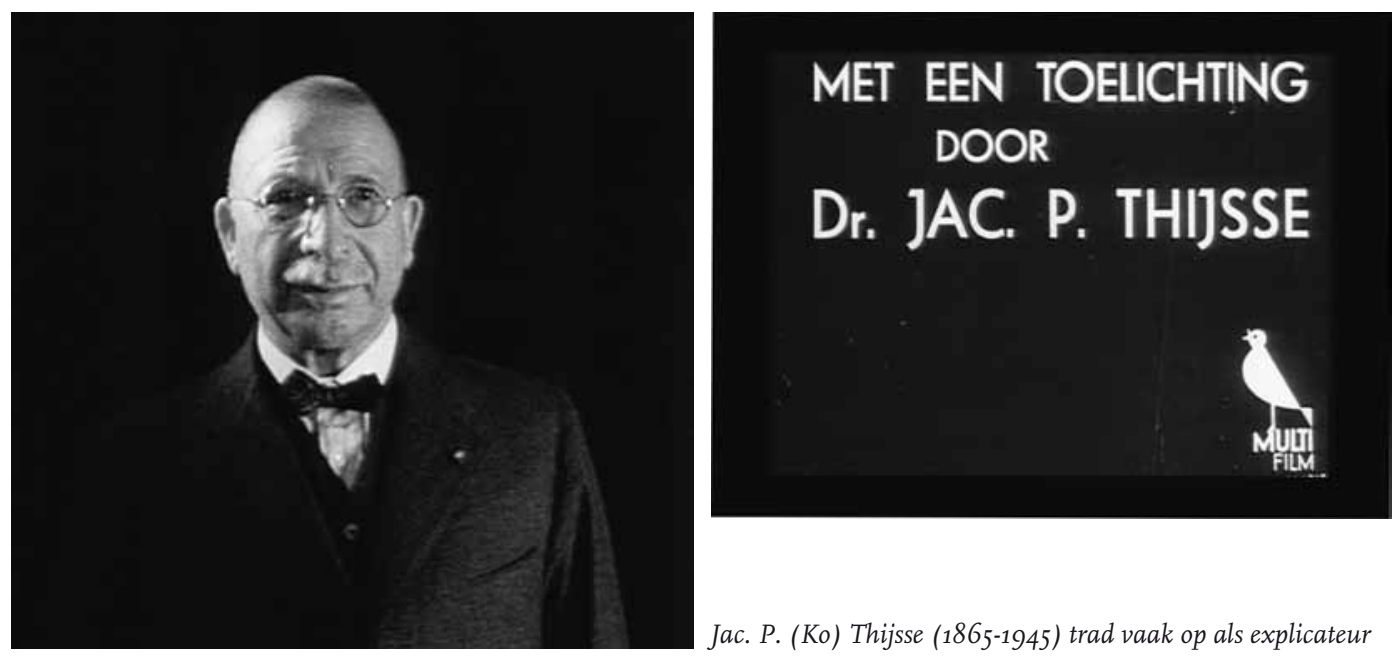

Jac. P. (Ko) Thijsse (1865-1945) trad vaak op als explicateur 
'Zoo kan ik u recommandeeren kemphaan I927, koekoek I925, wulp I92I, boschrietzanger 1924 enz.' 5

Behalve begrip creëren voor de natuur en het vogelleven in het bijzonder, speelden Burdets films ook een rol in wetenschappelijke controverses. Een goed voorbeeld waren de opnamen die hij maakte van een koekoeksjong in het nest van een roodstaart. Het was bekend dat koekoeken hun eieren lieten uitbroeden door andere vogels. Daarbij bleef in de praktijk vrijwel altijd alleen het koekoeksjong over, omdat de eigen jongen letterlijk buiten het nest vielen. Onduidelijk was of het de koekoeksouder, het jong dat net was uitgebroed of de 'pleegmoeder' was, die de andere bewoners uit het nest verwijderde. Burdet wist op celluloid vast te leggen hoe een koekoeksjong jonge roodstaartjes uit het nest verwijderde, terwijl hij nota bene door moeder roodstaart onder haar veren werd gekoesterd. Zelfs toen hij al kon vliegen werd de jonge koekoek nog door zijn 'pleegouders' van voedsel voorzien. Het viel Thijsse op hoe

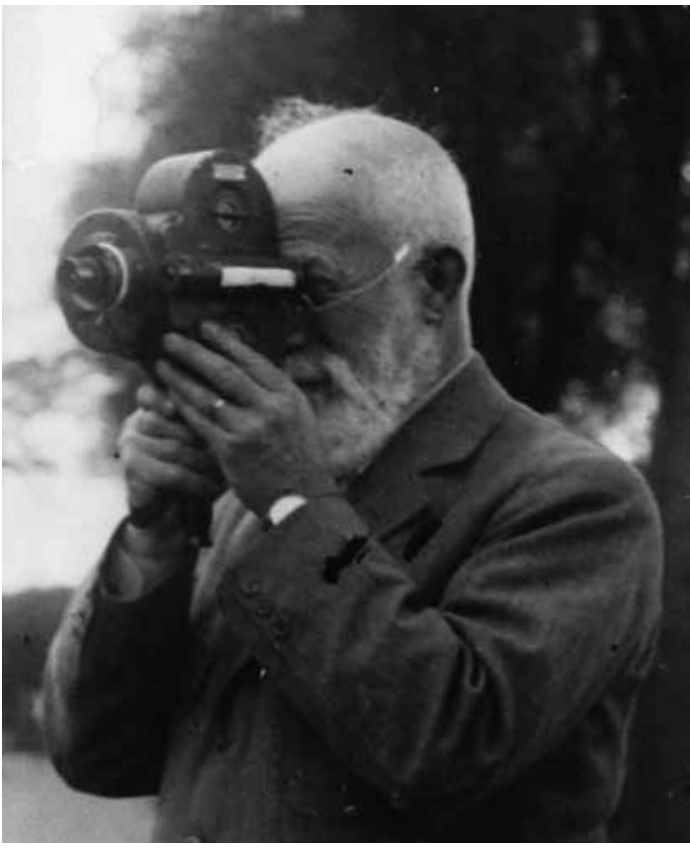

Vogelfilmer Ad(olphe) Burdet(1860-1940). Bron: alle afbeeldingen uit de vooroorlogse jaren zijn afkomstig van de DVD "Historische filmbeelden van Nederlandse vogelparadijzen", behorend bij: Frank Saris (samenst.), Een eeuw vogels beschermen (KNNV, Zeist 2007) verontwaardigd de toeschouwers raakten over de passiviteit van het roodstaart vrouwtje dat niets deed om haar eigen jongen van de dood te redden, en over de brutaliteit van het koekoeksjong. ${ }^{6}$

De afwerking van zijn films liet Burdet verzorgen door J.C. Mol die in I923 onder de naam Bureau voor Wetenschappelijke Cinematografie een eigen filmfabriek in Bloemendaal was begonnen.7 Toen Mol in 1927 de voormalige speelfilmstudio van Hollandia aan het Spaarne in Haarlem betrok en zijn bedrijf enige tijd later omzette in de naamloze vennootschap Multifilm, toonde Burdet zich bereid deze onderneming te steunen via de aanschaf van aandelen. Ook Jac. P. Thijsse volgde dit voorbeeld. Laatstgenoemde verzorgde de 'toelichting' bij MET DE FILMCAMERA DOOR DE VOGELWERELD, de eerste geluidsfilm met opnamen van Burdet, die in 1937 bij Multifilm werd gerealiseerd. In totaal maakte Burdet zo'n 25 films. Na zijn dood vervaardigde Nol Binsbergen er een compilatie van onder de titel voGELLEVEN IN HOLLAND (I94I).

Burdet kreeg al snel navolging van Jan P. Strijbos (I89I-I983). Deze Haarlemse natuurliefhebber was op jeugdige leeftijd begonnen met fotograferen. ${ }^{8}$ In I923 zette hij de volgende stap en kwam met zijn eerste film KENNEMER VOGELLAND. In tegenstelling tot de bemiddelde Burdet moest Strijbos met zijn activiteiten zijn brood zien te verdienen, nadat hij in I927 zijn baan als bouw- 


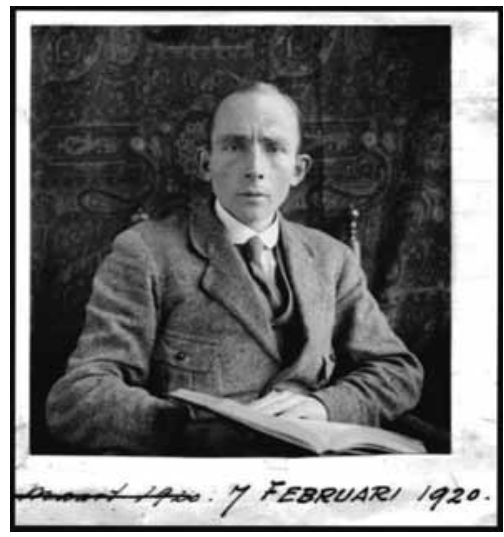

Jan P. Strijbos (1891-1983) in 1920

kundig tekenaar op het architectenbureau van zijn oom had opgezegd. Naast zijn publicistische werkzaamheden (hij had onder andere een rubriek in De Telegraaf en schreef meer dan veertig boeken), boden de films een belangrijke bron van inkomsten. Strijbos, die een boeiend verteller was, becommentarieerde ze live bij vertoningen voor de afdelingen van Volksuniversiteiten, de Maatschappij tot Nut van 't Algemeen en allerlei natuurorganisaties. Om de paar jaar kwam hij met een nieuwe film. In I932 wist hij Orion-Profilti zover de krijgen dat deze Haagse journaalmaatschappij een bioscooproulement verzorgde voor een korte, door hemzelf ingesproken geluidsfilm over de aalscholverkolonie bij Lekkerkerk. In de jaren dertig leende hij zich ook voor inleidingen op zogenaamde wetenschappelijke voorstellingen die een groeiend aantal bioscopen op zondagochtend organiseerde. Daarbij beperkte hij zich niet tot zijn eigen films maar presenteerde bijvoorbeeld ook de documentaire PANDION, DE VISCHAREND (AM HORST DER WILDEN ADLER, I932) van de Duitser Walter Hege.

$\mathrm{Na}$ verschillende films in Nederland gemaakt te hebben kwam Strijbos, die inmiddels op het veel handzamere $16 \mathrm{~mm}$ formaat was overgestapt, ook met filmverslagen van buitenlandse reizen. Zo filmde hij in IJsland, de Kurische Nehrung, de Shetlands, Spitsbergen en het Balkangebied. Toen hij op Spitsbergen van de buitenwereld afgesloten raakte omdat zijn kano was weggedreven, waren zijn vermissing en redding voorpaginanieuws. ${ }^{9}$ In I946 makte hij deel uit van de eerste naoorlogse walvisexpeditie met de 'Willem Barendsz' in de Zuidelijke Oceanen. Hij maakte zijn eigen film van de reis, naast wALvis iN zicht, de 'officiële film' van de hand van Polygoon-Profilti cameraman Hannes de Boer. Er volgden nog talloze reizen naar verre bestemmingen, die allemaal op film werden vastgelegd en steeds weer aanleiding waren tot een tournee

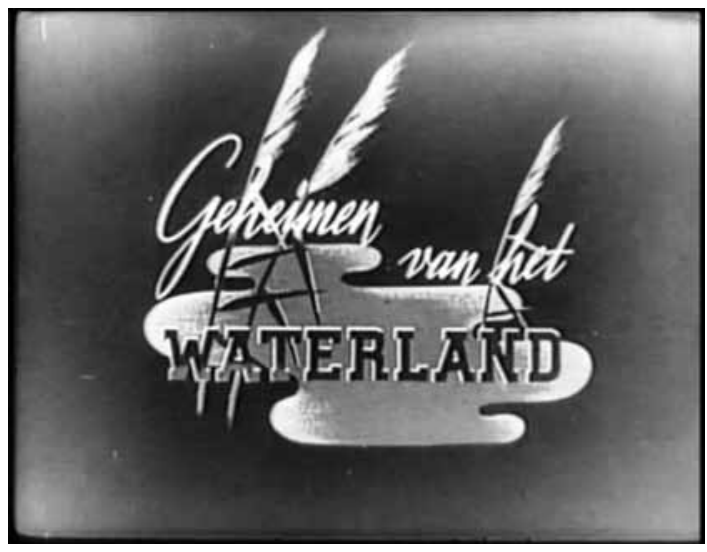

Nol Binsbergens filmtitel langs allerlei zalen. Maar Strijbos vergat ook Nederland niet en filmde onder meer in zijn geliefde Kennemerduinen, op de waddeneilanden en rond het Naardermeer. In de loop van de jaren zestig begon het publiek voor dergelijke vertoningen af te nemen, mede omdat er op de televisie steeds meer natuurfilms te zien waren.

Hoewel Nol Binsbergen (1908-1945) en Herman van der Horst (I9I0-I976) al voor de oorlog naam hadden gemaakt in kringen van natuurliefhebbers - respectievelijk als publicist en fotograaf en als preparateur begonnen beiden pas tijdens de bezetting aan 
hun eerste film over het Waddeneiland Texel. Opmerkelijk was dat ze voor deze film in de TESO (Texels Eigen Stoomboot Onderneming) een sponsor hadden gevonden. De contacten met de veerdienst waren een gevolg van de benoeming van Van der Horst tot directeur van het Texelsch Museum in 194I. Een deel van de opnamen van TEXEL, PAREL DER WADDENEILANDEN (I945) - de film zou pas na de bevrijding in première gaan - werd door de dankzij diens fotowerk meer ervaren Binsbergen gemaakt. De rest door Van der Horst die de filmtechniek snel onder de knie kreeg. ${ }^{10}$ De in de Zaanstreek woonachtige Binsbergen maakte nog twee andere films, GEHEIMEN VAN HET WATERLAND EN GEHEIMEN VAN HET RIETLAND, voordat hij in september I945 plotseling overleed. Van der Horst keerde nog tijdens de bezetting terug naar Beverwijk en sloot zich aan bij de groep van cineasten die opereerde vanuit de studio's van Multifilm in Haarlem en die na de bevrijding als de Neder-

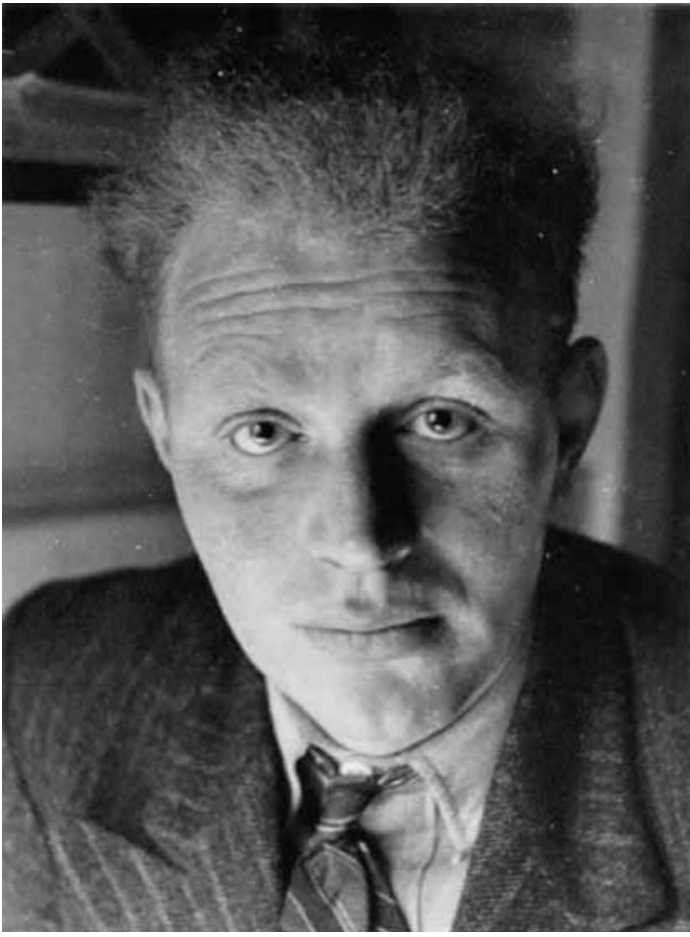

Filmer Nol Binsbergen (1908-1945) landse Werkgemeenschap voor Filmproductie (NWF) zou verdergaan. In de films die hij in de eerste jaren na de oorlog maakte, speelden natuur en natuurbehoud een belangrijke rol. Begin jaren vijftig kreeg hij internationale erkenning met de Marshall Hulp films 'T зснот is TE BOORD (I952) en HOUEN ZO! (I953). Zo slaagde Van der Horst erin de sprong van de niche van de natuurfilm naar de 'echte filmkunst' te maken. ${ }^{\text {II }}$

De natuurfilm bleef ook in de naoorlogse jaren de nodige aantrekkingskracht uitoefenen. Meestal hadden degenen die zich aan het maken van natuurfilms waagden, daarvoor al hun sporen verdiend in de natuurfotografie. Sprekende voorbeelden zijn Simon de Waard (I905-I986), Jan van den Ende (I922-2008), Will van Schieveen (geb. I93I) en Jan van de Kam (geb. I938). Zij maakten de nodige veranderingen mee op technisch gebied. Na films zonder geluid op $8 \mathrm{~mm}$, I6mm of $35 \mathrm{~mm}$ zwart/wit materiaal kwam Super 8 en I $6 \mathrm{~mm}$ kleurenmateriaal dat bovendien steeds sneller werd, evenals de mogelijkheid om synchroon geluid op te nemen. In de jaren tachtig volgde de overgang naar analoge en later zelfs digitale video. Ook veranderden de vertoningomstandigheden: van verenigingszaaltjes met een publiek van overtuigde natuurlief- 


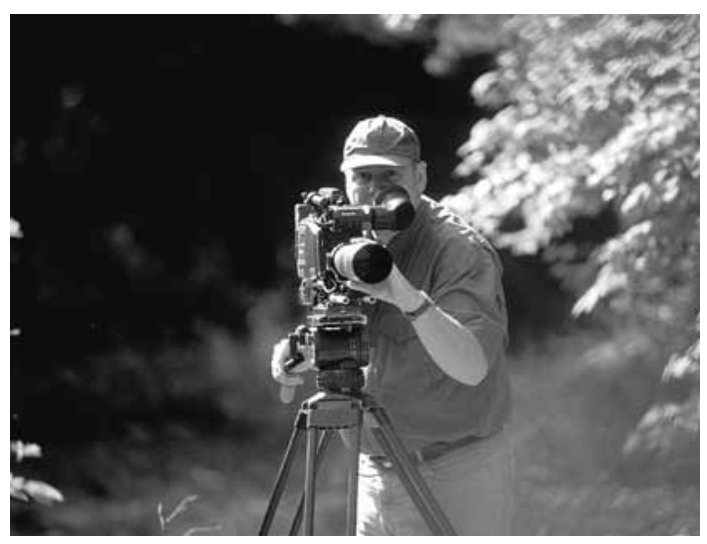

Filmer Luc Enting. Bron: foto Wim Kluvers
Bij ecoduct Terlet. Bron: foto Bas Worm, Enschede hebbers naar de huiskamers waar zappende kijkers elk moment de film kunnen afbreken.

De televisie betekende echter ook een kans voor natuurfilmers om ruimere financiering te vinden en continuïteit te bewerkstelligen. Zo wist een nieuwe generatie met behulp van de publieke omroepen in Hilversum en later ook van de regionale zenders een oeuvre op te bouwen. Maurice Nijsten (geb. I946) en Jo Erkens (1938-2008) verzorgden tussen I968 en I998 voor de KRO maar liefst 240 afleveringen van het programma NATUUR IN EIGEN LAND. ${ }^{\text {I2 }}$ Sinds 2000 maakt Nijsten een soortgelijk programma, NATUU RLIJ K LIM BU RG, voor de regionale zender LI. Hiervan zijn al ruim honderd afleveringen uitgezonden. Nadat Luc Enting (geb. 1957) in 1996 met zijn documentaire HET EDELHERT veel indruk had gemaakt, kreeg deze voormalig stedenbouwkundig tekenaar de kans om voor de TRos de televisieserie PUUR NATUUR (I997-2000) te realiseren. ${ }^{13}$ Hierbij was de financiële steun van Natuurmonumenten onontbeerlijk, want ook voor de publieke omroepen was (al dan niet verborgen) sponsoring inmiddels een noodzaak geworden.

Opmerkelijk genoeg was het de in Tanzania opererende filmmaker Hugo van Lawick (1937-2002) die in de jaren negentig een revival van de bioscoopdocumentaire in gang zette. Tot de jaren zeventig waren dergelijke films met enige regelmaat in de Nederlandse bioscopen te zien geweest. Ook op de zogeheten wetenschappelijke zondagochtendvoorstellingen of in de Cineacs konden

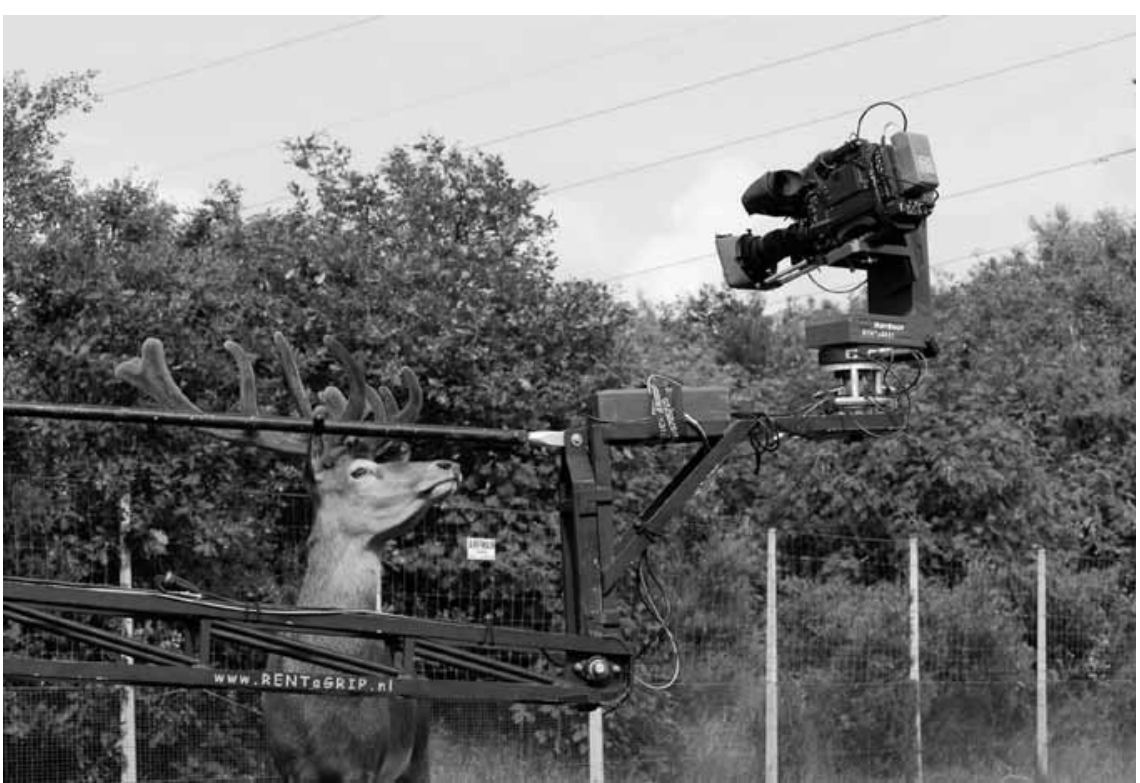


de liefhebbers van het genre toen aan hun trekken komen. Met Haanstra's ві DE BEESTEN AF - de enige lange natuurfilm van Nederlandse makelij met een uitgebreid bioscooproulement - werd dat tijdperk afgesloten. ${ }^{14}$ De maker van BIJ DE BEESTEN AF was in tegenstelling tot de hierboven genoemde filmers niet via de natuurbeweging opgestoten. De kwalificatie 'natuurfilmer' is eigenlijk niet op hem van toepassing. Haanstra (I9I6-I997) was een gelauwerd regisseur van documentaires en speelfilms met talloze prijzen op zijn naam - waaronder een Oscar voor GLAS (I958). ${ }^{\text {I5 }}$ Weliswaar had hij in I955 voor Shell een film over insecten gemaakt, maar qua retoriek voldeed STRIJD ZONDER EINDE bepaald niet aan de normen van de natuurfilm. De film betoogde dat insecten, vooral sprinkhanen, de natuurlijke vijanden van de mens waren en daarom met alle mogelijke (vooral chemische) middelen verdelgd dienden te worden. Haanstra raakte geïnteresseerd in de vergelijking van het gedrag van mensen en van dieren, zoals hij ook in zijn korte film zoo (1962) had laten blijken. Een 'onderzoek met behulp van de camera' stond centraal in BIj DE BEESTEN AF. In dat kader kwamen Haanstra en zijn vaste cameraman Anton van Munster in contact met Van Lawick die hen assisteerde bij het filmen van chimpansees in het Gombe reservaat in Tanzania. Dit bezoek maakte grote indruk op Haanstra. In twee latere films, CHIMPS ONDER ELKAAR (I984) en MONUMENT VOOR EEN GORILLA (I987), zou hij het ethologisch onderzoek naar mensapen voortzetten. ${ }^{16}$

Hugo van Lawick was begonnen als assistent bij Armand en Michaela Denis, het Belgisch-Amerikaanse echtpaar dat verantwoordelijk was voor de ook in Nederland zeer populaire televisieserie LUIPAARD OP SCHOOT (ON SAFARI, I957-I965). ${ }^{\text {I7 }}$ Daarna maakte hij als freelancer filmreportages voor de National Geographic Society, onder andere over de chimpansees in het bovengenoemde Gombe reservaat, waar zijn toenmalige vrouw Jane Goodall studie naar deed. Hij vestigde zich in het tentenkamp Ndutu in het natuurreservaat Serengeti in Tanzania. In de loop der jaren bouwde Van Lawick een grote library op met opnamen over het dierenleven aldaar. Hieruit putte hij onder andere voor PEOPLE OF THE FOREST (I988), een lange documentaire over twee chimpanseefamilies gedurende 25 jaar. Bert Haanstra verleende zijn medewerking aan de Nederlandse versie van deze film.

In de jaren negentig besloot Van Lawick te breken met de trend van $16 \mathrm{~mm}$ natuurfilms voor gespecialiseerde televisiekanalen als в вс, Discovery en National Geographic en $35 \mathrm{~mm}$ bioscoopfilms te gaan maken. Hij was van mening dat de schoonheid van het landschap van de Serengeti veel beter tot zijn recht kwam op het grote doek. Op deze manier wilde hij de toeschouwers emotioneel raken en hen bewuster maken van de noodzaak tot natuurbehoud. In THE LEOPARD SON (I996) en ADDO, KONING DER DIEREN (2002) paste hij een speelfilmachtige dramaturgie toe en gaf de 'hoofdrolspelers' menselijke trekken, zodat de kijkers zich beter met hen konden identificeren. Voor SERENG ETI SYMPHONY (I998) koos hij daarentegen juist voor een lyrische montage van fraaie beelden met een barokke score van Laurens van Rooyen. De drie films waren geprodu- 
ceerd door de Nederlandse productiemaatschappij Nature Conservation Films (NCF). Ook was Anton van Munster (I934-2009) die vanaf Alleman (I963) de vaste cameraman van Bert Haanstra was geweest, betrokken bij de opnamen. Van Munster zou ook na het overlijden van Van Lawick voor NCF in Tanzania blijven filmen. ${ }^{\mathrm{I}}{ }^{8}$

Een andere natuurfilmer wiens carrière zich grotendeels buiten Nederland afspeelde, was Peter Creutzberg (geb. I92I). ${ }^{\text {I9 }}$ Net als Van Lawick (en Van Munster) was ook hij betrokken geweest bij BIJ DE BEESTEN AF. Haanstra hem had gevraagd bepaalde opnamen in het Caraïbisch gebied te maken. Creutzberg, die aan de Rijksuniversiteit Leiden biologie had gestudeerd, was in I955 door de Stichting Culturele Samenwerking (Sticusa) naar Suriname uitgezonden om daar jongeren op te leiden tot filmmaker. Later had hij hetzelfde gedaan op de Nederlandse Antillen. De films die hij in de periode I955-I967 maakte, stonden in het teken van de economische ontwikkelingen in beide rijksdelen met 'modernisatie' als sleutelbegrip. In deze films was de natuur er om ontgonnen te worden tot landbouwgrond (ZWAM POOGST, I958), voor de buitenwereld ontsloten te worden door middel van airstrips (GEVLEUGELDE VEROVERING, I96I) of als recreatie te dienen voor de toeristen (OKE AKI ANTILLAS, I962). Voor CORsow (I966) waarvoor de Antilliaanse schrijver Boeli van Leeuwen het scenario schreef, werd hij onderscheiden met de Staatsprijs voor Film ig67. In deze film werden overigens vraagtekens gezet bij de idee van modernisering. Tussen I969 en I974 maakte Creutzberg die zich inmiddels in Colombia had gevestigd (waar hij nog steeds woont), een zevental films voor de Stichting Natuurbehoud Suriname (Stinasu). Doel van deze films moest zijn om in Suriname een 'nieuwe mentaliteit' ten aanzien van de natuur te bewerkstelligen. Om die reden moest, aldus Creutzberg, 'de presentatievorm zodanig (...) worden, dat alles ervaren kan worden als zuiver eigen, zuiver Surinaams'. ${ }^{\circ}$ Met behulp van shockerende beelden, een retoriek die haaks stond op die van zijn eerdere films en een commentaar dat hoorbaar door een Surinamer werd gesproken, liet hij zien hoeveel schade aan de Surinaamse natuur werd toegebracht en hoe door toedoen van de mens het voortbestaan van bepaalde diersoorten in gevaar kwam. Tussen I978 en I982 maakte Creutzberg een soortgelijke serie van dit keer vijf films op de Nederlandse Antillen, in opdracht van de Stichting Nationale Parken (Stinapa).

\section{Saai beest, mooi verhaal}

Jan Musch (geb. I95I) en Tijs Tinbergen (geb. I947) waren na de voltooiing van hun studie aan de Filmacademie in 1975 films gaan produceren, onder andere voor hun oud-klasgenoot Orlow Seunke (DE SMAAK VAN WATER, I982). Omdat ze na een jaar of acht genoeg kregen van het productiewerk, besloten ze zelf een film te gaan draaien. De keuze van het onderwerp, spreeuwen, diende zich 
aan door het onderzoek dat de broer van Tijs, de bioloog Joost Tinbergen, naar deze heel alledaagse vogelsoort verrichtte. De uitdaging voor Musch en Tinbergen was 'om met een relatief eenvoudig, en zo op het oog tamelijk saai beest, toch een mooi verhaal te vertellen'. In SPREEUWENWERK (I983) slaagden zij erin om wetenschappelijk onderzoek naar spreeuwen voor een groot publiek toegankelijk te maken, mede omdat ze de humor niet schuwden. Deze film die met een subsidie van het Ministerie van CRM tot stand was gekomen, werd twee keer op televisie uitgezonden. In I989 volgde in opdracht van de Nederlandse Vereniging tot Bescherming van Vogels een tweede natuurfilm van het duo, GANZEN PROBLemen? In deze film kwamen de verschillende standpunten van boeren, jagers en natuurbeschermers ten aanzien van de gans aan de orde.

Na GeBIOLOGEERD (I994), een persoonlijk portret van Joost Tinbergen en diens tamme spreeuw Peter - dat tevens een eerbetoon was aan Luuk Tinbergen, de jong overleden vader van Joost en Tijs - volgden films over rotganzen

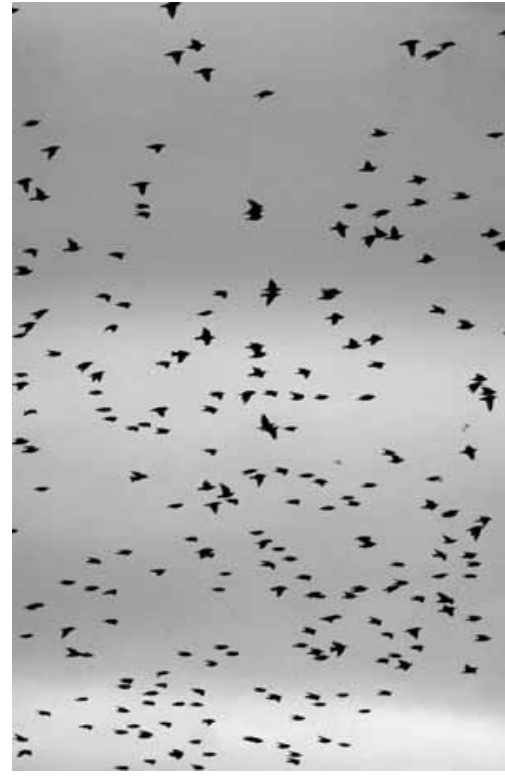

Spreeuwen. Foto: Lucia Heijselaar (ONZE ROTGANS IN SIBERIË, I996) en scholeksters (DE CARRIÈREPLANNING VAN DE SCHOleKSTER, I997). Hoewel Musch en Tinbergen hun protagonisten bij naam noemden (zoals het ganzenduo Theo en Thea en de scholekstermannetjes Sambo en Ludwig die om het vrouwtje Greta vechten), geschiedde dit in tegenstelling tot de natuurfilms van Disney of van Van Lawick niet om deze vogels menselijke eigenschappen toe te kennen. Het ging er de makers juist om hun handelingen rationeel voor de kijkers te verklaren. Voor zover de beelden van de vogels te weinig verklarend vermogen bezaten, lieten Musch en Tinbergen de biologen die hen in hun habitat bestudeerden aan het woord om voor aanvullende informatie te zorgen. De klassieke commentaarstem probeerden ze te vermijden. Dit uitgangspunt kon overigens niet altijd op instemming van de opdrachtgevers rekenen. Die zagen liever dat de boodschap zo expliciet mogelijk aan het publiek werd overgebracht, wat naar hun idee het beste kon met behulp van een commentaarstem.

Intussen hadden Musch en Tinbergen hun werkterrein uitgebreid. Zo maakten ze korte speelfilms voor de serie DE WERELD BOOT van de Voorlichtingsdienst Ontwikkelingssamenwerking, voor de Vereniging tegen Kindermishandeling, de Nederlandse Spoorwegen, de Consumentenbond, Stichting Consument en Veiligheid en een aantal ministeries. Jan Musch verzorgde steeds het camerawerk en de montage, terwijl Tijs Tinbergen voor het scenario en de regie tekende. Ook werden hun natuurdocumentaires breder van aanpak. In NIEUWE NATUUR (I996) stond bijvoorbeeld de metamorfose van het Nederlandse rivierlandschap centraal. In KOOS VAN ZOMEREN, LOPENDE ZINNEN (2002) werden de inspiratiebronnen van deze schrijver voor het voetlicht gebracht. Tijdens 
het Nederlands Film Festival 2009 is hun nieuwste film Rotvos in première gegaan en met een Gouden Kalf bekroond. De productionele sores van deze ambitieuze documentaire over de vraag of de vos, die van nature in de lage landen thuishoort, zelf mag bepalen of hij zich hier kan handhaven of dat anderen vanachter de tekentafel over zijn lot beslissen, besloten Musch en Tinbergen aan een andere producent, Selfmade Films, over te laten. Dit was een ongebruikelijke stap, want vrijwel alle natuurfilmers zijn tevens hun eigen producent.

De afgelopen jaren heeft de relatie tussen natuur en cultuurlandschap verschillende documentairemakers in de ban gehouden. De publicatie in 1999 van de Nota Belvedere over 'de kwaliteit van de inrichting van Nederland' had daartoe een stevige impuls gegeven. ${ }^{2 \mathrm{I}}$ Behalve bekende natuurfilmers als Luc Enting (BEDEVAART VOOR DE NATUUR, 2007) en Musch en Tinbergen (BeVloGEN WATERLAND) lieten ook andere filmmakers zich door dit thema inspireren. Zo legt Digna Sinke sinds 1996 vast hoe op het eiland Tiengemeten landbouwgrond aan de natuur wordt teruggegeven. Deze langetermijn observatie heeft inmiddels geresulteerd in TIENGEM ETEN deel I (200I) en TIENGEMETEN 200I2006 (2006), terwijl een derde en laatste documentaire op komst is. Eugenie Jansen en Albert Elings filmden zeven jaar lang de veranderingen in de uiterwaarden bij Loowaard (vOORLAND, 2005). In OP DE GRENS (2005) onderzocht Peter Delpeut natuur en natuurbeleving aan de oevers van het IJ.

\section{Stijl en techniek}

Omdat er weinig onderzoek naar is gedaan, is het onvermijdelijk dat dit korte overzicht van Nederlandse natuurfilmers lacunes vertoont. ${ }^{22}$ Maar er zijn wel voldoende makers en hun films aan bod gekomen om iets meer over de ontwikkeling van technieken en de toepassing van stijlen te kunnen zeggen. In de beginjaren was het filmmateriaal nog weinig gevoelig, terwijl er met de camera's - met de hand aangezwengeld of met een veerwerk uitgerust - opnamen van slechts korte duur gemaakt konden worden. Ook werkte het mechaniek van de camera (nog zonder blimp) bepaald niet geruisloos. Van Ad. Burdet is bekend dat hij de vogels aan dit geluid liet wennen door aan een koffiemolen te draaien. Later gebruikte hij hiervoor een speciaal voor hem vervaardigde ratelaar.

Voor Burdet was de camera op de eerste plaats een hulpmiddel bij het veldonderzoek. Hoe meer verschillende vogelsoorten hij wist vast te leggen, des te meer voldoening dit hem schonk. Uitgangspunt was de overtuiging dat de camera niet kon liegen. Vandaar de enorme impact van Burdet's filmopnamen van het gedrag van een koekoeksjong in het nest van een 'gastgezin', waarover onenigheid heerste in ornithologische kringen. Ook werden de films van Burdet ingezet als propaganda voor de natuurbescherming in bredere zin. Hiervoor was echter wel de aanwezigheid van een goed van de tongriem gesneden explicateur, zoals Jac. P. Thijsse, onontbeerlijk. 

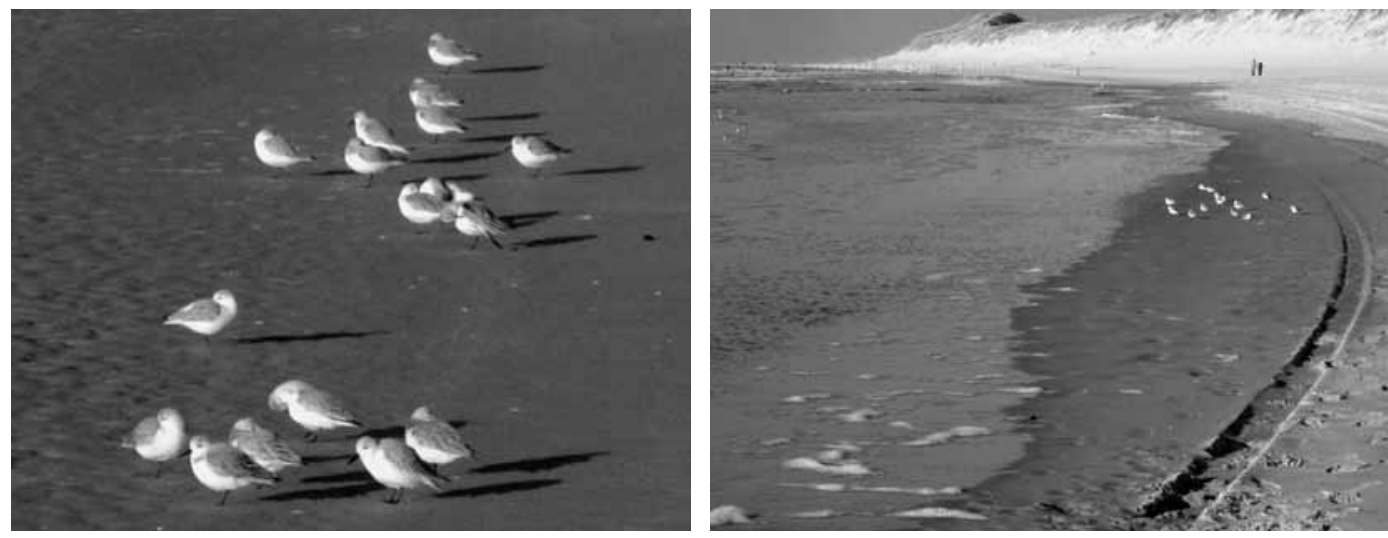

Strandlopers aan de

Jan P. Strijbos worstelde in de jaren twintig en dertig met dezelfde technische Noordzeekust. Foto's: handicaps als Burdet. Later werden lenzen en filmmateriaal gevoeliger en kon redactie hij ook over kleurenfilm beschikken. In zijn films was al meer sprake van een 'verhaal', of liever gezegd van de bewuste rangschikking van de bouwstenen voor dat verhaal. Want het was Strijbos zelf die met behulp van de filmbeelden live het verhaal vertelde. Eigenlijk waren zijn films 'halffabrikaten' die alleen geconsumeerd konden worden als er een essentieel element aan werd toegevoegd: de persoonlijke explicatie van de auteur. ${ }^{23}$ Hiermee plaatste Strijbos zich in een traditie waarin de maker expliciet als gids in zijn of haar natuurfilm, respectievelijk -televisieprogramma aanwezig is. Bekende voorbeelden zijn Martin en Osa Johnson, Armand en Michaela Denis, Jacques-Yves Cousteau, Bernhard Grzimek en David Attenborough. Tenzij men presentatoren als Han Rensenbrink, die in de (veilige) ruimte van de televisiestudio bleven, meerekent, vond deze traditie geen navolging in Nederland.

Het 'eindfabrikaat', het filmverhaal werd verteld met beelden; een keuze uit (al dan niet synchroon opgenomen) geluiden, muziek en/of gesproken commentaar werd de standaard voor natuurfilms. Met TEXEL, PAREL DER WADDENEILANDEN (I945) werd hiervoor de toon gezet. Deze film van Nol Binsbergen en Herman van der Horst was een typische opdrachtfilm zoals er in Nederland in die jaren talloze werden gemaakt. Hoofdzaak was het op een positieve manier in beeld brengen van het onderwerp (het vakantie-eiland Texel), liefst met expliciete aandacht voor de opdrachtgever (de veerdienst TESO). In een recente bundel hebben Vinzenz Hediger en Patrick Vonderau gesteld dat de opdrachtfilm, in het bijzonder de bedrijfsfilm, drie terreinen bestrijkt: dat van de record, de rhetoric en de rationalization. ${ }^{24}$ De eerste twee (de film als 'document' waarin iets voor later wordt vastgelegd, en de aandacht die besteed wordt aan het 'overtuigen' van de kijker) zijn van toepassing op veel Nederlandse natuurfilms. Het derde begrip, het vooruitgangsideaal dat zo dominant aanwezig is in veel bedrijfsfilms, lijkt echter niet geschikt. De vooruitgang wordt juist gezien als een bedreiging voor de natuur. Veel natuurfilms zijn dan ook 
eigenlijk natuurbeschermingsfilms. Daarom zou het begrip rationalisation misschien beter vervangen kunnen worden door Darwinism (ook al begint dat woord niet met een R), aangezien de strijd om het voortbestaan in de natuur wel een terugkerend thema is.

De reputatie van Van der Horst en Haanstra als documentaristen in aanmerking genomen, ligt het voor de hand om ook hun natuurfilms in de categorie 'documentaire' te plaatsen. Natuurfilms van andere makers worden vaak eveneens als documentaires beschouwd. In zijn boek Wildlife Films (2000) stelt Derek Bousé echter dat 'conceptually, procedurally, and formally, if not also thematically, most of the accepted practices in documentary film making simply may not apply to films with wild animals as subjects. ${ }^{25}$ Inderdaad zijn natuurfilms waarin wilde dieren het onderwerp zijn, niet te vergelijken met documentaires met mensen in de hoofdrol. Je kunt dieren niets vragen. Het voordeel is wel dat je ze geen vrijwaringverklaring hoeft te laten ondertekenen. Ook is het geluid in natuurfilms zelden synchroon opgenomen, terwijl dit bij documentaires juist als een teken van authenticiteit geldt. Toch zijn er onder de Nederlandse natuurfilms wel degelijk producties aan te treffen die met recht documentaires genoemd kunnen worden. Zelfs als een dier(soort) de hoofdrol speelt. Een goed voorbeeld is Rotvos (2009) van Jan Musch en Tijs Tinbergen, die niet voor niets een Gouden Kalf voor de beste lange documentaire ontving.

Het gaat om films als die van Hugo van Lawick en zijn navolgers bij Nature Conservation Films, waarvan Bousé van mening is dat ze geen documentaires zijn. Hoewel documentaire (niet-geënsceneerde) beelden ten grondslag liggen aan de films, maken ze gebruik van speelfilmtechnieken om de toeschouwer te boeien. Individuele dieren - niet hun hele soort - spelen de hoofdrol en de commentaarstem vertolkt als het ware hun gevoelens. Een goed voorbeeld van die aanpak is ADDO, DE KONING DER DIEREN (2002), waarin de jeugd en adolescentie van een leeuw centraal staan. Via een soort monologue intérieur wordt de toeschouwer op de hoogte gesteld van emoties als vreugde, verdriet en angst bij Addo. Met dit type natuurfilm, bedoeld voor een groot publiek, borduren Van Lawick en NCF voort op de True Life Adventure serie (I948-I960) van Walt Disney. ${ }^{26}$

Deze traditie heeft in Nederland verder weinig navolging gekregen. Een van de verklaringen hiervoor is gelegen in het feit dat Nederlandse natuurfilmers altijd met bescheiden budgetten hebben moeten werken. Bij gevolg zijn er geen Nederlandse equivalenten van succesvolle bioscoopfilms als MicrocosMOS (I996), Le PeUPLe MigRATOIR (2002) en DeEP Blue (2003) met hun hoge production values en hun spectaculaire gebruik van nieuwe technologieën. Toch bieden de technologische ontwikkelingen ook makers in Nederland nieuwe mogelijkheden. Digitale camera's met cassettes of hard disks staan veel langere takes en dus intensievere observatie toe dan de $35 \mathrm{~mm}$ of $\mathrm{I} 6 \mathrm{~mm}$ camera's voorheen. Het is tegenwoordig mogelijk om nachtopnamen te maken zonder dat er extra belichting aan te pas hoeft te komen. Entingfilms, de productie- 
maatschappij van Luc Enting, heeft al geëxperimenteerd met het gebruik van webcams. Zo werd een op afstand bestuurbare camera geplaatst bij het nest van een zeearend in de Oostvaardersplassen. Door middel van een straalverbinding werden de beelden doorgestuurd naar het op zes kilometer afstand gelegen bezoekerscentrum van Staatsbosbeheer. Vandaar gingen ze naar de website van Staatsbosheer, waar de unieke beelden online te bewonderen waren. Inmiddels zijn er ook producenten actief die alleen nog maar voor het internet werken, zoals Rombus Films in Nijmegen. ${ }^{27}$

Tentoonstellingen

Zoals in de inleiding van dit artikel is vermeld hebben het Nederlands Instituut voor Beeld en Geluid en het Nationaal Natuurhistorisch Museum Naturalis het initiatief genomen tot het project 'Collectie Nederlandse Natuurfilms'. In dat kader werken medewerkers van Beeld en Geluid en van Naturalis samen vanuit twee perspectieven: de filmer en de natuur. Zo willen zij het erfgoed aan Nederlandse natuurfilms ontsluiten voor geïnteresseerden in natuurprogramma's, de natuurorganisaties, producenten, uitgevers en het onderwijs. Een projectsubsidie in 2008 van de Bankgiro Loterij maakte het mogelijk om een inventarisatie te starten van natuurfilms door Nederlandse makers en zo tot een collectieoverzicht te komen.

De collectie natuurfilms van Hugo van Lawick is een belangrijke bron voor het beeldmateriaal bij twee familietentoonstellingen die door de projectsubsidie mogelijk werden. Focuste de tentoonstelling zOom SAFARI (juni 2008-januari 2009) van Beeld en Geluid op de techniek en de visie van de filmer, de tentoonstelling WILDE BEESTEN (vanaf oktober 2008) van Naturalis legt de nadruk op de beleving van de natuur in de Serengeti. Bij Beeld en Geluid werden in de tentoonstelling ZOOM SAFARI ook beelden getoond uit films van Bert Haanstra, Jan Musch en Tijs Tinbergen, Maurice Nijsten en Jo Erkens en van Luc Enting.

De voorbereiding voor de tentoonstellingen leidt tot digitalisering van materiaal uit het archief van Beeld en Geluid waardoor natuurfilms tevens beschikbaar komen in een resolutie voor gebruik in websites. De collectiebeschrijvingen in het archief aanvul-

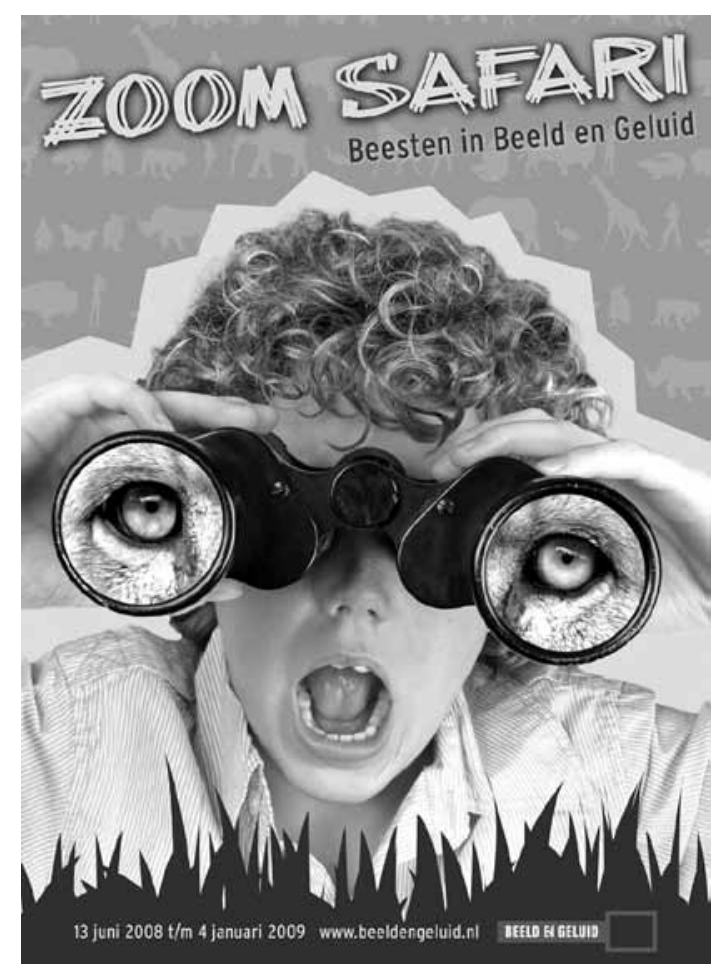


len en verrijken met verhalen en biografieën draagt bij aan de duiding van de Nederlandse natuurfilm als fenomeen. Via het webportaal Natuurinbeeld.nl en reguliere websites zoals de Beeldengeluidwiki.nl, Teleblik.nl, Academia.nl, Natuurinformatie.nl, Natuurkaart.nl, Walvisstrandingen.nl en het Soortenregister.nl worden Nederlandse natuurfilms en natuurdocumentaires toegankelijk. ${ }^{28}$ Natuurorganisaties en anderen kunnen hun eigen informatie koppelen aan de collectie-items of rechtstreeks verwijzen naar een dossier, pagina of fragment. Hieraan was grote behoefte, zoals bleek uit een verkennend onderzoek dat in 2008-2009 werd uitgevoerd. ${ }^{29}$

\section{Verkenning}

Om de algemene stemming te peilen ten aanzien van het project Collectie Nederlandse Natuurfilm zijn omroepen en natuurorganisaties benaderd. Uit de reacties bleek dat diverse natuurorganisaties over een eigen archief met natuurbeelden beschikken. De kwaliteit van deze 'archieven' is sterk verschillend. Waar bij de een het materiaal al geordend en soms al gedigitaliseerd is, ligt het bij de ander in dozen ongeordend opgeslagen. Bij veel natuurorganisaties was het lastig om een aanspreekpunt te vinden omdat er vanuit verschillende disciplines zoals communicatie, fondsverwerving, ledenwerving en beleidsbeïnvloeding met beeldmateriaal wordt gewerkt en de verantwoording voor ontwikkeling, gebruik en beheer ervan dus niet bij één persoon ligt. Bij de omroepen is het beeldmateriaal meestal al aanwezig in het archief van Beeld en Geluid. Dit geldt niet voor de regionale omroepen die aangeven dat ze over materiaal beschikken dat mogelijk interessant zou zijn voor de Collectie Nederlandse Natuurfilm.

Er zijn maar enkele natuurorganisaties die gebruikmaken van het brede potentieel van natuurfilms. Bij de meeste heerst een afwachtende houding, hoewel men wel degelijk beseft dat bewegend beeld steeds belangrijker wordt in de communicatie. Het liefst wil men films die de natuur in eigen land in beeld brengen. Slechts een enkele (internationale) natuurorganisatie is geïnteresseerd in internationale thema's. Binnen het totale aanbod van de landelijke omroepen is de rol van natuurfilms niet groot. Wel is voor enkele van hen het thema natuur zo belangrijk dat ze het doortrekken naar de activiteiten voor de leden. Ze hebben evenveel belangstelling voor materiaal dat in Nederland is geschoten als voor films die zich in het buitenland afspelen. De regionale omroepen zijn vooral geïnteresseerd in materiaal over de directe omgeving van hun uitzendgebied. Een dialoog is wenselijk tussen natuurorganisaties en omroepen over de vraag aan welke onderwerpen het meest behoefte is.

Op enkele uitzonderingen na is er weinig kennis bij de natuurorganisaties over opdrachtverlening en productieproces. Als een film eenmaal is gemaakt, blijkt er ook nauwelijks beleid te zijn ten aanzien van de actualisering van het 
getoonde onderwerp. Diverse organisaties maken gebruik van amateurbeelden die door leden of sympathisanten zijn gemaakt. De kosten die hiermee verbonden zijn, zijn veel beperkter dan die van professionele producties, waarvoor vaak apart een beroep moet worden gedaan op externe financiële hulp. Ook bij de omroepen zijn de budgetten voor natuurfilms beperkt.

Voor een specifiek onderdeel van het project Collectie Nederlands Natuurfilms, namelijk het digitaal beschikbaar stellen van het materiaal (onder de noemer DCN - Digitale Collectie Nederlandse Natuurfilms), bestaat aanzienlijke belangstelling, zowel onder de natuurorganisaties als onder die omroepen die actief natuurfilms vertonen. Men verwacht dat het makkelijk kunnen vinden en toepassen van beeldmateriaal het gebruik ervan zal stimuleren. ${ }^{\circ}$

\section{Slot}

De Nederlandse natuurfilm heeft een lange traditie. Veel makers zijn jarenlang actief geweest en hebben een aanzienlijk oeuvre opgebouwd en beschikken meestal ook over een grote library aan 'losse' beelden. Bovendien komen er steeds weer jonge makers bij. Ook zijn er de nodige amateurs op dit terrein actief. Natuurfilms zijn populair bij het grote publiek. Toch heeft de natuurfilm in Nederland vergeleken met de Angelsaksische wereld een lage status. De door de omroepen beschikbaar gestelde budgetten zijn bescheiden. Opdrachtgevers uit de natuurbeweging hebben vaak moeite om de benodigde middelen bijeen te brengen. Er is geen vereniging die opkomt voor de belangen van de Nederlandse natuurfilmers. Prestigieuze prijzen zijn alleen op buitenlandse festivals te behalen (het Gouden Kalf voor RoTvos is een uitzondering die deze regel bevestigt). Ook ontbreekt een overzicht van wat er aan natuuropnamen gemaakt is - of het nu om gisteren of vijftig jaar geleden gaat. Evenmin is het altijd duidelijk waar die opnamen bewaard worden: bij de makers, de natuurorganisaties die de opdracht ertoe hebben gegeven of de archieven (Beeld en Geluid, Filmmuseum en dergelijke). Om die reden is het project Collectie Nederlandse Natuurfilm van start gegaan.

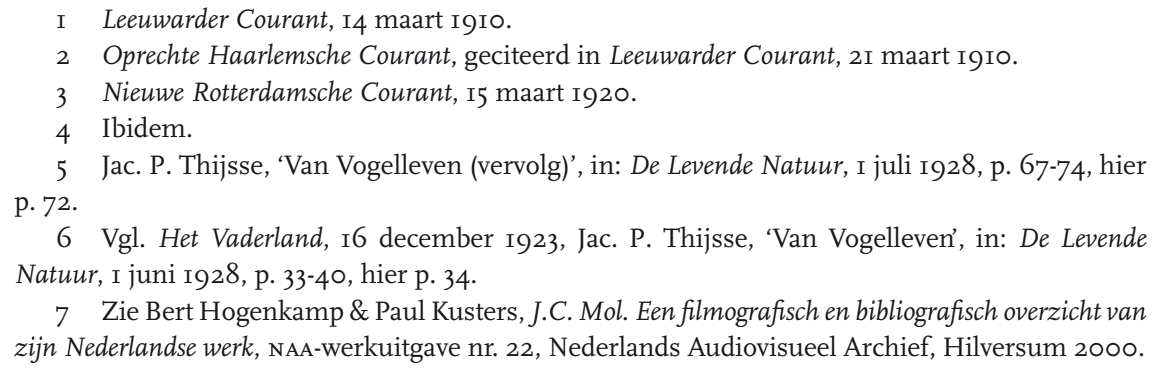

6 Vgl. Het Vaderland, i6 december I923, Jac. P. Thijsse, 'Van Vogelleven', in: De Levende Natuur, I juni I928, p. 33-40, hier p. 34 .

7 Zie Bert Hogenkamp \& Paul Kusters, J.C. Mol. Een filmografisch en bibliografisch overzicht van zijn Nederlandse werk, NAA-werkuitgave nr. 22, Nederlands Audiovisueel Archief, Hilversum 2000. 
8 Zie 'Strijbos, Jan Pieter', in: K.H. Voous, In de ban van vogels, Scheffers, Utrecht I995, p. 47I.

9 Vgl. Het Vaderland, 27 juli I939, 28 juli I939 en 29 juli I939. Ook het Polygoonjournaal besteedde aandacht aan het avontuur in de vorm van een gesprek van Jac. P. Thijsse met Jan P. Strijbos, weeknummer 39-32.

IO Een opname van de in I940 overleden Ad. Burdet die in TeXel, PAREL DeR WAdDENEILANDEN is verwerkt, wijst erop dat voor deze film gebruik is gemaakt van oudere beelden die al voor de afspraken met de TESO (door Binsbergen?) waren geschoten.

II Zie Bert Hogenkamp, De Documentaire Film 1945-1965. De bloei van een filmgenre in Nederland, Uitgeverij oIо, Rotterdam 2003, passim

I2 Zie http://www.mauricenijsten.nl/ (geraadpleegd op 27 oktober 2009).

I3 Zie http://www.entingfilms.nl/ (geraadpleegd op 27 oktober 2009).

I4 Zie hier ook de bijdrage van Hans Schoots over Bert Haanstra's BIJ DE BEESTEN AF.

I5 Zie Hans Schoots, Bert Haanstra. Filmer van Nederland, Mets en Schilt Uitgevers, Amsterdam 2009 .

I6 Als spin-off van BIJ DE BEESTEN AF stelde Haanstra ten behoeve van het wetenschappelijke onderwijs in I972 nog een negental korte films samen onder de titels ETHOGRAMMEN (drie films) en VERGELIJKENDE ETHOLOGIE TUSSEN MENS EN Dier (zes films). Ze werden door de Stichting Film en Wetenschap gedistribueerd. Deze films staan overigens niet vermeld in de Haanstra filmografie in Hans Schoots, Bert Haanstra.

I7 Vgl. http://www.wildfilmhistory.org/person/93/Hugo+van+Lawick.html (geraadpleegd op 22 oktober 2009).

I8 Op het Nederlands Film Festival 2009 is de film SURvivor waarin veel beeldmateriaal van Van Munster is verwerkt, in première gegaan. Vgl. http://www.ncf-nl.com/index2.html (geraadpleegd op 27 oktober 2009).

I9 Zie Bert Hogenkamp, 'Peter Creutzberg: pendelaar tussen verschillende culturen', in: Beeld voor Beeld. Documentary Film Festival on Cultural Diversity 2009, Beeld voor Beeld, Amsterdam 2009, p. 24-26.

20 Peter Creutzberg, 'Advies inzake films Natuurbescherming Suriname', I969, in: archief Sticusa, inventarisnummer 2.I0.27.04, bestanddeel 570, Nationaal Archief, 's-Gravenhage.

2I Zie http://www.belvedere.nu/index.php?section=OI (geraadpleegd op I5 september 2009).

$22 \mathrm{Zo}$ is geen aandacht besteed aan de wetenschappers die films ten behoeve van hun onderzoek hebben gemaakt, zoals de etholoog Niko Tinbergen (I907-I988).

23 Dit gold ook voor andere makers van reisfilms, zoals Paul Julien, Alphons Hustinckx en Theo Regout. Vgl. Bert Hogenkamp, De Documentaire Film 1945-1965. a.w., p. I45.

24 Vinzenz Hediger, Patrick Vonderau, 'Record, Rhetoric, Rationalisation. Industrial Organization and Film', in: Vinzenz Hediger \& Patrick Vonderau (eds), Films that Work. Industrial film and the productivity of media, Amsterdam University Press, Amsterdam 2009, p. 35-49.

25 Derek Bousé, Wildlife Films, University of Pennsylvania Press, Philadelphia 2000, p. 24.

26 Bousé, Wildlife Films, p. 62-70.

27 Zie http://rombus.nl/ (geraadpleegd op 27 oktober 2009).

28 Zie ook het schema hier opgenomen in het Redactioneel, en de websites die bijvoorbeeld in de bijdrage over Naturalis worden genoemd.

29 Collectie Nederlandse Natuurfilms. Verkenning Natuurorganisaties en Omroepen, April 2009.

30 Ibidem. 